DOI 10.38129/ Ann.Yur.Ist.2019.3.1.2.105

УДК 352.075.1

\title{
УТВОРЕННЯ І ПОЧАТКИ ФУНКЦІОНУВАННЯ СЯНОЦЬОГО ГРОДСЬКОГО УРЯДУ ТА ІНТЕГРАЦІЯ СЯНОЦЬКОЇ ЗЕМЛІ ДО СКЛАДУ ПОЛЬСЬКОГО КОРОЛІВСТВА В XIV-XV ст.
}

\author{
МИХАЙЛО ТУПИЦЯ (Львів, Україна)*
}

Гродські суди - це система судово-адміністративних установ, що утворювались навколо головного їх урядника - старости (capitaneus) ${ }^{1}$, та початково були судами першої інстанції для неосілої шляхти. Уряд старости, за твердженнями дослідників, був для середньовічного Польського королівства характерним і звичним інститутом ${ }^{2}$, котрий набув значної політико-юридичної ваги у період правління династії Пшемисловичів. Старости зазвичай були намісниками короля на місцях. Місцем здійснення безпосередніх повноважень старости вважався місцевий (локальний) замок - грод (лат. castrum); звідси походить назва установи.

Історіографію генези та хронології початку розвитку гродських судовоадміністративних установ у Польському королівстві розглянув та узагальнив дослідник М. Павліковський․․ Джерела до вивчення сяноцького гродського судочинства (вживається також термін «судівництво») зосереджено здебільшого у виданнях «Актів гродських і земських». Узагальнюючи відомості про гродське судочинство, М. Павліковський робить висновок, що у новоприєднаних землях Польської корони протягом XIV ст. ще не було такого самого здійснення судочинства, як на інших землях держави. Реформування судової гілки влади було покликане консолідувати, інтегрувати та певною мірою централізувати Королівство Польщу. Відтак, важливим інструментом та кроком для забезпечення королівського авторитету на місцях була приватна спадкова власність на землю.

Сяноцька земля, як юридична одиниця адміністративнотериторіального устрою, ввійшла до складу Польського королівства

${ }^{1}$ Bardach J. Historia państwa i prawa Polski. Warszawa, 1973. T. 1. S. 124.

${ }^{2}$ Kutrzeba S. Starostowie ich początki i rozwój w XIV wieku. Kraków, 1903. S. 92; Bardach J. Historia państwa i prawa... - S. 256.

3Pawlikowski M. Sąownictwo grodzkie w przedrozbiorowej Rzeczypospolitej. Strzałków, 2012. S. 12. 
набагато раніше інших земель колишнього Галицько-Волинського князіства (в окремі періоди також і королівства).

За даними писемних джерел, академік М. Грушевський припускає, що Сяноцьку землю було формально включено до територіальної юрисдикції Корони Польської ще в 40-х роках XIV ст. ${ }^{4}$.

Окрім суто політичного аспекту, вважаємо, що серед причин приєднання Сяноцької землі до Польського королівства, очевидно був і географічний фактор, який полягав у безпосередній близькості цієї землі до столиці Королівства Польського - Кракова. Сяноцька знать охоче сприймала та навіть ініціювала 5 політико-юридичні зміни. Це стосується не лише досліджуваного нами періоду часу. Як відомо, Сянок був заселений німецьким католицьким населенням ще за княжих (галицько-волинських) часів, а в 1339 р. отримав німецьке міське (магдебурзьке) право. Під впливом настроїв і культурно-політичних орієнтацій, які привозили із собою західні колоністи-католики, враховуючи подальше приєднання до складу Польщі не за «правом меча», сяноцька руська шляхта почувалась доволі впевнено і могла дозволити собі самоврядування без королівського дозволу, що дефакто було надзвичайно позитивним явищем для держави як політикоюридичного організму6.

Зауважимо, що за княжої доби всю актову документацію писали староукраїнською мовою, але впродовж цілого XV ст. всі документи Сяноцького самоврядування були писані вже виключно латинською мовою iз деякими незначними вкрапленнями польської7. Це також варто взяти до уваги при розгляді питання про культурно-правову інтеграцію.

Земельні наділи та система судівництва - це прямо пов'язані речі (як у минулому, так і сьогодні). Дуже часто вони ставали причинами звернення до суду. Володіння та випадки легального відчуження земельних наділів шляхтою залишались надзвичайно гострими соціальними питаннями у другій половині XIV - першій половині XV ст. Протягом цього періоду королі багаторазово видавали привілеї щодо непорушності права на

\footnotetext{
4 Грушевський М. Історія України-Руси. Київ, 1993. Т. IV. С. 31.

5 Дорошенко Д. Нарис історії Украйни. Львів, 1991. Т. 1. С. 136.

6 Przyboś K. Wstęp / / Urzędnicy Wojewódstwa Ruskiego XIV-XVIII wieku (Ziemie Halicka, Lwowska, Przemyska, Sanocka): Spisy. Wrocław, 1987. S. 11; Крикун М. Земські уряди на українських землях у XV-XVIII ст. // Записки Наукового товариства імені Шевченка. Том CCXXVIII. Праці Історико-філософської секції. Львів, 1994. С. 65.

${ }^{7}$ Akta grodzkie $i$ ziemskie $z$ czasów Rzeczypospolitej Polskiej $z$ archiwum tak zwanego bernardyńskiego we Lwowie (далі - AGZ). Lwów, 1886. T. XI. S. 1-488; Tam że. T. XVI. S. 1-424
} 
володіння маєтками, які повторювали та уточнювали одне одного.

У вказаний хронологічний відтинок часу бачимо активне змагання королівської влади із шляхетськими правовими апетитами на теренах цілого королівства. Від Кошицького привілею 1374 p. ${ }^{8}$ до Нєшавського 1454 p. можна прослідкувати чітку тенденцію - шляхта змогла задовольнити свою потребу в недоторканності приватної спадкової власності на землю9. У контексті цих подій сяноцька шляхта не могла

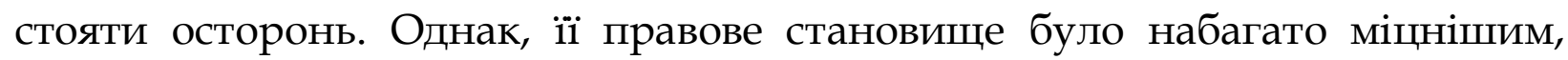
аніж в шляхетському середовищі решти територій Галицької Русі.

Джерела до розкриття теми можна умовно розподілити за хронологічним принципом на кілька етапів. Визначені нами періоди в історії становлення польського права на руських землях показують, яким саме чином проводились інтеграційні процеси, а також характер і форми впливу політичних еліт на процедури інтеграції.

Перший етап: 40-ві роки XIV ст. - 1423 р. Цей проміжок часу має досить малу кількість джерел, що лише частково розкривають процеси інтеграції, але побіжні згадки про уряди та урядників демонструють процес початку рецепції польської системи самоврядування та судівництва.

Другий етап: 1423-1434 pp. Його можна умовно назвати «старостинським». Цей період представлений актовими документами, що ілюструють елементи судівництва в Сяноцькому гроді. Тематика актів $є$ доволі різноманітною та абсолютно не диференційована за тематичним принципом. В архівному «портфелі» присутні судові, і майнові, і фінансові, і земельні справи.

Третій етап: 1434 р. - кінець XV ст. Цей етап є завершальним у процесі правової інтеграції Сяноцької землі. В 1434 р. було остаточно реалізовано адміністративну реформу. Проте вона не поклала край побутуванню елементів місцевої руської (княжої) системи судочинства.

До кінця XV ст. процес інтеграції завершився і Сяноцька земля мала доволі типовий для Польщі гродський уряд. Із місцевої специфіки залишився поділ на гродові повіти, проте він стосувався цілого Руського воєводства. Конкретно, Сяноцький гродський уряд мав повноваження на теренах Сяноцької землі та повітів: Сяноцького, Динівського і Тичинського. При цьому, гродський судовий повіт називався Сяноцьким незалежно від

${ }^{8}$ Matuszewski J. S. Przywileje i polityka podatkowa Ludwika Wegierskiego w Polsce. Łódź, 1983. S. $62-70$.

9 Goźdź-Roszkowski K. Z badań nad Nietykalnością majątkówą polskiej szlachty. Postanowienia przywilejów z lat 1386 - 1454 // Studia z Dziejów Państwa i Prawa Polskiego. T. 10. Kraków, 2007. S. 30-32. 
того де засідав уряд в той чи інший хронологічний період ${ }^{10}$.

Периферійні території мали певні відмінності у функціонуванні як інститутів влади, так i господарчих форм економіки. Найдавніші документи із Сяноцького гродського уряду, що дійшли до нашого часу демонструють типове поєднання давнього руського та польського права. Хоч, у співвідношенні до корінних польських земель, Сяноцька земля була периферією, однак чітке визначення повноважень старост турбувало місцеву знать настільки ж сильно, наскільки й шляхту цілого королівства11. Як відомо, край у соціальних непорозуміннях поклав Вартський статут 1423 р. Його головні постанови (так звані чотири гродські артикули) полягали в обмеженні повноважень старостинського суду. До розглядання у старостинських судах відтоді належали справи, що стосувалися гвалту, викрадення, розбою на дорогах, нападів на маєтки та підпалів ${ }^{12}$.

Правовий фронтир Галицької Русі сприяв поєднанню руської та польської систем права, з перевагою першої над другою до 1434 р. Для прикладу, у стольному воєводському місті Львові впроваджують дві посади старости: генеральний руський староста та староста львівський. Крім цього староство існувало і в самому Сяноку ${ }^{13}$. Новоутворене Руське воєводство було «земельним», так як поділялось на землі. Ці землі відповідали юрисдикційним округам, тобто це були земські та гродські судові повіти. При цьому, судово-адміністративна ієрархія копіювала всі уряди столиці воєводства (Львова). Відмінним було лише те, що для цілого воєводства був лише один воєвода ${ }^{14}$, а сяноцький воєвода мав статус гродського.

Адміністративні нововведення на руських землях до реформи $1434 \mathrm{p}$. стосувалися здебільшого введенням посад, які пізніше стали фігурувати у земських урядах. Свідченням доволі жвавої інтеграції Сяноцької землі до Польського королівства виступає згадка про каштелянію в Сяноку

${ }^{10}$ Купчинський О. А. Земські та гродські судово-адміністративні документальні фонди Львова // Прикладна архівістика та спеціяльні історичні дисципліни. Вибрані статті та матеріали. Львів, 2011. Т. 2. С. 500.

11Kutrzeba S. Starostowie... S. 118.

${ }^{12}$ Hencel A. Z. Starodawne prawa polskiego Pomniki: Starodawne prawa polskiego Pomniki poprzedzone wywodem historyczno krytycznym tak zwanego Prawodawstwa Wiślickiego Kazimierza Wielkiego w texcie ze starych rekopism krytycznie dobranym. Warszawa, 1856. T. 1. S. 319 .

${ }^{13}$ Szyszka J. Kształtowanie się podziałów terytorialnych Rusi Czerwonej na przykładzie ziemi lwowskiej // Średniowiecze Polskie i Powszechne. Katowice, 2011. T. 3 (7). S. 125.

${ }^{14}$ Крикун М. Земсъкі уряди... С. 87. 
(«castellania Sanocensi») вже в 1359 p. ${ }^{15}$ ! Але посада каштеляна та ім'я самого урядника згадуються аж 7 листопада 1433 р.! В цьому документі Петро Смоліцький (Petro Smoliczky) притягується до суду через сплату неповної суми боргу братам Миколаю (Nicolaus), Млечку (Mleczko) та Кжиштку (Krzisztek), синам пана Пшедслава (Przedslaw) ${ }^{16}$. Казімєж Пшибось припускає, що згадуваний в актах від 12 жовтня 1412 p. Миколай де Блочішов (Mikołaj de Bloczischow) імовірно був каштеляном ще при Владиславі Опольському17.

Зміна у судочинстві означала зміну в правах та обов'язках місцевого населення, властиво аристократії. Галицькі еліти у складі Польського королівства відчували себе дещо приниженими. Після завоювання Галицької Русі місцева знать мала статус особистих слуг короля і змушена була виконувати королівські розпорядження під загрозою втрати земель ${ }^{18}$. Після боротьби за галицьку спадщину частина місцевої знаті була позбавлена свого попереднього статусу а частина хотіла отримати нагороду за підтримку польського короля. Так, за бажанням, а не всупереч знаті було ініційовано адміністративну реформу 1434 р., що включала зміну в місцевому судівництві.

Вище ми вже з'ясували, що шляхта Сяноцької землі мала дещо інакшу систему самоврядування до реформи 1434 р. ніж решта Галицької Русі. Місцевий судово-адміністративний орган був за своєю природою земським, але судові рочки проводили в замку і називали його гродським. Збережені дотепер акти дозволяють підтвердити цей факт. Не було поділу не конкретно земельні та конкретно кримінальні справи. Усі судові провадження записували до єдиної системи книг, що називались «Рочки Сяноцькі» («Termini Sanocenses») 19 .

Склад Сяноцького суду до реформи містив досить незвичайні поєднання посад та їх ієрархії. Так у Сяноцькому гроді присутні наступні посади: староста, суддя, воєвода, писар земський, асесори ${ }^{20}$. При цьому звичайний, типовий гродський уряд мав у своєму складі старосту головного урядника. Суддю і писаря зазвичай призначав староста. Крім

${ }^{15}$ AGZ... - T. III. S. 25.

16 AGZ... - T. XI. S. 82.

17 Przyboś K. Wstęp // Urzędnicy Wojewódstwa Ruskiego XIV-XVIII wieku (Ziemie Halicka, Lwowska, Przemyska, Sanocka): Spisy. Wrocław, 1987. S. 10.

18 Бойко I. Органи влади і право в Галичині у складі Польського Королівства (1349-1569 рр.). Львів, 2009. С. 144.

${ }^{19}$ AGZ... T. XI. S. 1-90.

${ }^{20}$ Pietruski O. Liske X. Przedmowa // AGZ. Lwów, 1886. T. XI. S. VII. 
суддівських повноважень староста був намісником короля та охоронцем замку і підпорядкованої йому адміністративної округи ${ }^{21}$. Сяноцький староста був земельним і підпорядковувався старості руському, що був воєводським 22 .

Персонал Сяноцького дореформенного уряду нагадує поєднання гродського та земського урядів. Це $є$ суд земський, але в значенні відмінному від того, яке надавала земським судам реформа $1434 \mathrm{p}$. Звичайно, тут ще домінувало руське право. Староста тут є головним урядником та суддею в широкому розумінні. На час своєї відсутності староста призначав заступника (vice-capitaneus). Коли староста Миколай Хжонстовський (Mikołaj Chrząstowski) 1432 р. виїхав у справах до короля, призначив замість себе Петра Смоліцького (Piotr Smolicki), який титулував ceбе vice-capitaneus та навіть capitaneus ${ }^{23}$. Йому підпорядковувався земський суддя, що розглядав усі справи, які надходили до установи. При цьому, він був радником старости, а не самостійним суддею. Самостійно суддя вів менш важливі провадження у час відсутності старости або за його смерті. У час відсутності або смерті судді староста міг за своїм бажанням призначати на цю посаду будь яку людину. Посада воєводи також була заснована на старому руському праві, але в XV ст. ії вже сприймали на польський манір, називаючи його воєвода гродський ${ }^{24}$. Швидше за все, означення воєводи «гродським» базувалось на тому, що він виконував свої обов’ язки при замку та підкорявся владі старости. Підлеглість воєводи старості демонструється поведінкою старости щодо уряду. Певний час староста міг призначати на цю посаду земських дворян, вони часом мали статус особистих слуг старости. Подеколи староста не призначав сталого воєводи. Цього урядника в актах титулують vice-voyevoda або voyevoda protunc.

Повноваження старости на изому етапі розвитку судової системи Польського королівства залежали від особи, щзо носила иеей титул. Традиційно адміністративні посади надавали добре знаним шляхтичам. При цьому, від заможності та розгалуженості клієнтської мережі конкретного старости залежав вплив старости, а звідси і цілого гродського уряду. Гродський уряд, як і інші уряди у Польському королівстві, формували в першу чергу не як юридичну установу, а як громадське коло людей, що їх очолював головний

${ }^{21}$ Крикун М. Земсъкі уряди... С. 81-82.

22 Там само. С. 92.

${ }^{23}$ AGZ... T. XI. S. 72-74.

24 Hejnosz W. Jus Ruthenicale. Przeżytki dawnego ustroju spolecznego na Rusi Halickiej w XV wieku // Studya nad Historya Prawa Polskiego. Lwów, 1928. T. 12, ż. 1. S. 29-31. 
урядник, у даному випадку староста. Це була звичайна практика, оскільки більшість урядів формували з метою реалізації практичних «комунальних» потреб, а не для того, щоб було більше можливості отримувати вищий статус у суспільстві через володіння тим чи іншим урядом.

Деякі зловживання з боку шляхти у володінні земськими урядами спостерігаємо вже у XVI ст.

Після реформи постали дві окремі судово-адміністративні установи. Так сталось і на інших територіях Польського королівства. Відтак, ієрархія гродського уряду від найвищого до найнижчого урядників виглядала так: староста, гродський суддя, воєвода (гродський) і писар. Земський уряд очолив воєвода. Крім нього були: каштелян, гродський староста, суддя, підсудок і писар. В Сяноцькій землі попередній земський писар став писарем при земському уряді 25 .

Питання про статус воєводи залишається в історико-правовій науці досить нечітким. У документах воєвода згадується від середини XIV ст. Иого відповідником у XIV ст. виступає уряд бурграбія. Уряд «Burgravio de Sanok» вперше згадується у 1359 р. ${ }^{26}$, а згадку 1373 р. Томка Вашоти як «Palatino nostro Sanocensi» дослідники вважають за потрібне потрактувати як бурграбія 27. Джерела показують, що уряд бурграбія виступав в ролі відповідника гродському воєводі, але від середини до кінця XV ст. встиг витіснити останнього із титулування урядника. Цей процес показує, щзо елементи місиевої правової традииї̈ залишалися у Сяноиькій землі щзе доволі довго після впровадження польського права.

Отже, інтеграційні процеси в Сяноцькій землі відбувалися поступово, протягом близько півтора століття. Виклики, що постали перед польськими королями в справі консолідації та централізації королівства передусім реалізовувались через принцип верховенства права. Їх найяскравішим проявом стали зміни в судовій системі. Самоврядування та судочинство, як гілки виконавчої та судової влади, в той час ще були досить слабо диференційовані.

Документальна спадщина Сяноцького старостинського, а згодом гродського і земського урядів дозволяє нам розділити процеси політичної інтеграції цієї землі. Протягом всього періоду XIV-XV ст., що представлений у джерелах досить нерівномірно та неповно, помітно сталу тенденцію ненасильницького насадження нових принципів

\footnotetext{
${ }^{25}$ Крикун М. Земсъкі уряди... С. 80; AGZ... T. XI. S. IX.

${ }^{26}$ AGZ... T. III. S. 27.

27 Tam że. T.VII. S. 16.
} 
самоврядування та їх охочого прийняття місцевими елітами. При цьому, сяноцькій знаті, після боротьби за галицьку спадщину, не загрожувала настільки велика небезпека втрати земельних наділів як елітам інших територій Галицької Русі.

Найдавніші збережені документи сяноцького суду не носять конкретної назви, що б відповідали певному статусу цього уряду. Та все ж схиляємося до думки, що уряд, за принципами фрормування більш схожий на гродський. Проте документація цього суду за тематикою може відноситись як до гродського так і до земського. Але, враховуючи прийняття Вартського статуту 1423 р., уряд і далі приймав та розглядав справи, що не були передбачені сферою його безпосередніх повноважень.

Отож, інтеграція Сяноцької землі до складу Польського королівства, через призму формування старостинського, а згодом і гродського уряду показує: цей процес мав чітко виражений політичний характер, охопивши терени не тільки локальної землі, але й цілого королівства.

\section{ЛІТЕРАТУРА}

1. Akta grodzkie i ziemskie z czasów Rzeczypospolitej Polskiej z archiwum tak zwanego bernardyńskiego we Lwowie. Lwów, 1872. T. III (1872), VII (1878), XI (1886), XVI (1894).

2. Hencel A. Z. Starodawnego prawa polskiego Pomniki poprzedzone wywodem historyczno krytycznym tak zwanego Prawodawstwa Wislickiego Kazimierza Wielkiego w texcie ze starych rekopism krytycznie dobranym. Warszawa, 1856. T. 1. $428 \mathrm{~s}$.

3. Бойко I. Органи влади i право в Галичині у складі Польського Королівства (1349-1569 рр.). Львів, 2009. 625 с.

4. Грушевський М. С. Історія Украӥни-Руси. Київ, 1993. Т. IV. 535 с.

5. Дорошенко Д. І. Нарис історії Украӥни. Львів, 1991. 576 с.

6. Крикун М. Земські уряди на українських землях у XV-XVIII ст. Записки Наукового товариства імені Шевченка. Том ССХХVIII. Праці Історикофрілософської секиії. Львів, 1994. С. 65-122.

7. КупчинськийО. А. Земські та гродські судово-адміністративні документальні фонди Львова. Прикладна архівістика та спеціяльні історичні дисципліни. Вибрані статmі та матеріали. Львів, 2011. Т. 2. 755 с.

8. Bardah. J. Historia państwa i prawa Polski. T. I: Do połowy XV wieku. Warszawa, 1965. 587 s.

9. Kutrzeba S. Starostowie: ich początki i rozwój w XIV wieku. Kraków, 1903. $120 \mathrm{~s}$.

10. Pawlikowski M. Sądownictwo grodzkie w przedrozbiorowej 
Rzeczypospolitej. Strzałków, 2012. 144 s.

11. Przyboś K. Wstęp. Urzędnicy Wojewódstwa Ruskiego XIV-XVIII wieku (Ziemie Halicka, Lwowska, Przemyska, Sanocka): Spisy. Wrocław etc., 1987. 415 s.

12. Matuszewski J. S. Przywileje i polityka podatkowa Ludwika Wegerskiego w Polsce. Łódź, 1983. 252 s.

13. Goźdź-Roszkowski K. Z badań nad Nietykalnością majątkówą polskiej szlachty. Postanowienia przywilajów z lat 1386-1454. Studia z Dziejów Państwa i Prawa Polskiego. T. 10. Kraków, 2007. S. 15-32.

14. Szyszka J. Kształtowanie się podziałów terytorialnych Rusi Czerwonej na przykładzie ziemi lwowskiej. Średniowiecze Polskie i Powszechne. Katowice, 2011. T. 3 (7). S. 120-140.

15. Hejnosz W. Jus Ruthenicale. Przeżytki dawnego ustroju spolecznego na Rusi Halickiej w XV wieku. Studia nad Historia Prawa Polskiego. Lwów, 1928. T. $12, \dot{z} .1$.

MA Mykhailo Tupytsia (Lviv, Ukraine)

\section{ESTABLISHMENT AND BEGINNING OF THE FUNCTIONING OF THE SANOK GOVERNMENT AND THE INTEGRATION OF SANOK LAND TO THE POLISH KINGDOM IN XIV-XV centuries.}

The article tells about the acquisition of traditional Polish law in the territory of Galicia. The historiography of the problem and sources that have already been published, but not involved in this kind of research, are considered. The legal traditions of the Middle Ages in Central-Eastern Europe thus were able in some way to unite the rights of the two civilizations - the Catholic West and the Eastern Orthodox. The merging of the Rus and Polish legal cultures is examined on the example of the history of institutions, and in this case the main attention was drawn to the castle court. The castle courtwas chosen to see how the process of introducing Polish legal institutions to the territory of the Sanok Land of the Rus province was proceeding. In order to track down the process of integrating the legal system of the Sanok Land, we analyze the sources and look for the first mentions of those or other offices that were not inherent in the local law before. The reasons for the course and consequences of the integration of the Sanok Land are represented by thinking about the role of the local and alien aristocracy. Understanding the integration process is facilitated by the proposed periodization of historical sources of research. For its establishment, the principle of the availability of the sources and the specificity of their separation after the administrative reform of 1434 is taken. At the same time, the general picture of the composition of the Sanok castle courtis presented before and after the reform. The territory of jurisdiction and the scope of authority of this institution are also presented in this article. At the same time, it must be said that often in medieval practices there was a significant personal factor that was associated with the economic and political influence of a particular official.

Key-words: Sanok Land, Sanok Castle, Sanok Government, Galicia, Polish Kingdom. 
магистр Михаил Тупиця (Львов, Украина)

СОЗДАНИЕ И НАЧАЛО ФУНКЦИОНИРОВАНИЯ САНОЦКОГО ГРОДСКОГО ПРАВЛЕНИЯ И ИНТЕГРАЦИЯ САНОЦКОЙ ЗЕМЛИ В СОСТАВ ПОЛЬСКОГО КОРОЛЕВСТВА (XIV-XV вв.).

Статья рассказывает о рецепции традиционного польского права на территории Галицкой Руси. Рассматривается историография проблемы и источники, которые уже были опубликованы, но не привлекались к такого рода исследованиям. Автор утверждает, что правовые традиции Средневековья в Центрально-Восточной Европе смогли объединить правовые культуры двух цивилизаций - католической западной и православной восточной. Слияние русской и польской правовых культур рассматривается на примере истории юридических учреждений, и, в данном случае, основное внимание автора привлек гродский суд. Саноцкий гродский суд избран для того чтобы посмотреть, каким образом протекал процесс внедрения польских правовых институтов на территории Саноцкой земли Руского воеводства. Чтобы проследить процесс интеграции правовой системы Саноцкой земли, проанализированы и найдены первые упоминания о тех или иных должностях, которые не были свойственны здешнему самоуправлению ранее. Причины, ход и последствия интеграции Саноцкой земли представлены размышлением о роли местной и пришлой аристократии (шляхетства). Понимание процесса интеграции облегчает предлагаемая автором периодизация исторических источников для данного исследования.

Ключевые слова: Сяноцкая земля, Сяноцкий замок, Сяноцкое самоуправление, Галиция, Польское королевство.

магістр Михайло Тупиця (Львів, Україна)

УТВОРЕННЯ І ПОЧАТКИ ФУНКЦІОНУВАННЯ СЯНОЦЬОГО ГРОДСЬКОГО УРЯДУ ТА ІНТЕГРАЦІЯ СЯНОЦЬКОЇ ЗЕМЛІ ДО СКЛАДУ ПОЛЬСЬКОГО КОРОЛІВСТВА В XIV-XV ст.

Стаття розповідає про впровадження традиційного польського права на території Галицької Русі. Розглядається історіографія проблеми і джерела, які вже були опубліковані, але не залучалися до такого роду досліджень. Автор стверджує, що правові традиції Середньовіччя в Центрально-Східній Свропі змогли об'єднати правові культури двох цивілізацій - католицької західної і православної східної. Злиття руської та польської правових культур розглядається на прикладі історії юридичої установи - гродського уряду. Гродський уряд обраний автором для того, щоб подивитися, яким чином протікав процес впровадження польських правових інститутів на території Сяноцької землі Руського воєводства. Щоб відслідкувати процес інтеграції правової системи Сяноцької землі проаналізовані джерела та знайдені перші згадки про посади, які до того часу не були властиві тутешнім юридичним практикам. Причини, хід та наслідки інтеграції Сяноцької землі представлені роздумами про роль місцевої та прийшлої аристократії (шляхти).

Ключові слова: Сяноцька земля, Сяноцький замок, Сяноцьке самоврядування, 
Галичина, Польське королівство.

* Тупиця Михайло Васильович - магістр історичних наук історичного факультету Львівського національного університету імені Івана Франка. E-mail: mr.tupytsia@gmail.com. 